\title{
英米両国におけるホームレス政策の再構築の方向性に関する考察 \\ 一OECD 諸国におけるホームレス政策に関する研究（その2）一 \\ ANALYSIS OF THE WAY HOMELESS POLICIES ARE RESTRUCTURED \\ IN THE USA AND UK
}

\author{
長谷川 貴彦* \\ Takahiko HASEGAWA
}

\begin{abstract}
The paper attempts to describe the recent trend of increasing homeless population in the USA and UK, and to analyse how governments are restructuring their homeless policies for improving the cost-effectiveness of their policies. The analysis has identified several common trend in restructuring in both countries, such as the emphasis of holistic approach, assigning more responsibility to local governments, targeting the scope of policies, introducing prevention approach and improving economic efficiency of NPO's activities. These findings should provide useful insights for improving the cost-effectiveness of homeless policies in other countries.
\end{abstract}

Keywords : Homeless policies, Housing policies, US, UK, OECD

ホームレス政策、住宅政策、米国、英国、OECD

\section{1.はじめに}

ホームレス人口の增加は我が国でも大きな問題となりつつあるが、 欧米諸国においては、1970-80 年代よりホームレス人口が急増し、ホ ームレス問題を解決するための政策（ホームレス政策(1)）が、既存の 社会政策及び住宅政策等の枠組みと連携しながら導入されてきている。 米国及び英国は、これらの国の中でも、ホームレス問題に関する取組 みについて特に長い歴史を有している国である。両国においては、 1970～80 年代に導入されたホームレス政策の基本的枠組みのもと、 1980 年代から 1990 年代にかけてホームレス人口が漸減してきていた ものの、1990 年代の後半からホームレス人口が增加する傾向にあり、 ホームレス政策の再構築が試みられている。

米国及び英国(2)におけるホームレス政策については、長年にわたり、 ホームレス問題の多様性を反映し様々な調査・分析が行われてきてい る。例えば、英国のホームレス政策については、担当省庁である英国 副総理府 1)等が政策提言の文書を多数発表し、政府の監察機関である 英国監察庁 2)が様々な政策関係の分析・提言をおこなっているほか、

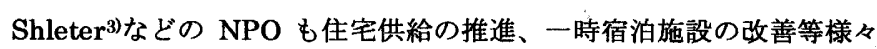
な政策提言を行っている。学術分野においても、Greve ら 4)、Balchin ${ }^{5)}$ などが主として住宅供給の必要性の点を議論しているほか、住宅政策 の柱となる住宅法の地方レベルの運用について、Butler ら 6)、Niner ら7などが分析を行っている。さらに、Randall ら 8)、Burns ら 9)など
が主として路上生活者や簡易宿泊施設宿泊者らの居住対策に絞った政 策について、多くの分析を行っているほか、Hutson 5 10)、Fischer ら 11は、ホームレスに対するきめ細かな福祉サービスの提供の重要性 を強調している。

米国においても、米国ホームレス庁 12)や米国住宅都市開発庁 13)が既 存の政策手法について、有効性を改善するための政策提言を行ってい るのに対して、National Coalition for the Homeless ${ }^{14)}$ などの NPO が より積極的な取り組みを求める提言を行っている。学術分野では、 Basuuk ら 15)、Belcher ら 16)など多くの専門家が、1980年代より、ホ ームレスの病理面での分析に基づき、医療政策の改善の必要性を強調

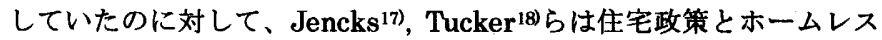
との関連性を分析し、住宅関連の手法の重要性を論じたほか、 O'Flaherty ら 199は住宅市場モデルを用いた分析を行っている。また、 Burt ら 200は、ホームレスの属性に関する経験的調查を多数行い、連続 性の高い政策デザインの必要性などの提言を行っている(3)。

このように両国のホームレス政策に係る調查・分析は数多いが、上 述のように、どの政策手法を重視すべきかと言う点について、個々の 国の文脈で論じているものがほとんどで、両国のホームレス政策につ いての共通点・相違点について比較・分析したものは、Daly ${ }^{211 に よ る ~}$ 分析など一部にみられるものの、特に近年のホームレス政策の動向に 関するものは見当たらない状況である。 
このような状況の中で、経済協力開発機構（OECD）は、2002-3 年に、ホームレス政策に関するケーススタディーの一環として、米国 及び英国のホームレス政策の近況について分析を行った(4)。近年、 OECD 諸国においては財政支出を抑制し小さな政府をめざすことが 共通のトレンドとなっていることを背景に、政策の費用対効果を高め ることがあらゆる政策分野で重要課題となっていることを踏まえ、本 分析においても、ホームレス政策の費用対効果の面が特に重点をおか れた。

本稿は、2003 年春まで OECDに在籍し、本調查を責任者として担 当した筆者が、本調查を通じて得られた情報をもとに、政策の費用対 効果の観点を中心に、米国及び英国における近年のホームレス政策の 状況を分析するとともに、ホームレス人口の再増加という状況に直面 した両国におけるホームレス政策の再構築の方向性について比較・分 析を行い、その共通点等について考察を行おうとするものである。

\section{2. 調查の方法}

両国におけるホームレス関俰の情報を文献調查により収集・分析し たほか、2003 年 1-3 月に、中央政府でホームレス政策を担当してい る英国副総理府 (Office of Deputy Prime Minister)、米国ホームレス 対策庁 (Interagency Council on Homelessness)、地方自治体レベルで ホームレス政策を推進するロンドン市(Greater London Authority)及 びニューヨーク市 (New York City Government)、さらにホームレス関 連の活動を展開している NP0（英国：Shelter 及び Salvation army，米 国 : National Coalition for the Homeless 及び The Partnership for the Homeless) の担当者に対してインタビュー等を行った(5)。こうし たプロセスにより得られた情報をもとに、両国におけるホームレス政 策の再構築の方向性について分析を行った。

\section{3. 米国及び英国におけるホームレス人口の動向}

“ホームレス”（Homeless）の定義は国により異なるが、英国では住 宅法において、「占拠する法的権利を有し、アクセス可能かつ物理的に 使用可能で、継続して居住することが合理的である宿泊場所を有さな い者」と定義されており、また、米国ではマッキニー・ベント法にお いて「固定され定常的で十分な機能をもつ夜間の宿泊場所を持たず、 夜間の主たる宿泊場所が一時宿泊施設等である者」という定義が連邦 政府に採用されている(6)。ホームレス人口の正確な把暒は技術的に容 易でなく、OECD 諸国においてもホームレス人口に関するモニタリング の仕組みは十分に整備されていない。英国は、ホームレス人口自体を 定期的かつ直接的にカウントし、ホームレスが何人いるかというデー 夕を把握する仕組み整備されていないものの、ホームレス人口との関 連性が強く信頼性も比較的高い時系列データを有する数少ない国のひ とつである ${ }^{22)}$ 。英国においては、後述のとおり、住宅法に基づき、一 定の要件を満たすホームレス世帯に対して恒久的住居を提供すること が、地方自治体に義務付けられているが、この規定に基づき地方自治 体が受け入れたホームレス世帯の数が、ホームレス問題の深刻さを示 す指標として活用されている(7)。地方自治体に受け入れられたホーム レス世帯数は、1980 年代に増加を続け、1991 年に年間約 14 万世帯の ピークに達した後減少に転じたが、図 1 に示すとおり、1997 年の約 10 万世帯で底打ち、近年は増加傾向にある。英国のホームレス問題の深 刻さを示すもうひとつの重要な指標が、一時的宿泊施設に滞在するホ
ームレス世帯数である。地方自治体は、住宅法に基づき受け入れたホ ームレス世帯に提供する恒久的住居が確保できるまでの間、当該世帯 に対して一時的住居を提供することが義務付けられており、地方自治 体や NP0 の運営する一時的宿泊施設、Bed and Breakfast hotel（以下 「B\&B」という。）と呼ばれる簡易なホテルや民間貨貸住宅などが活用 されている。

一時的宿泊施設に滞在するホームレス世帯数についても、図 2 に示 すとおり、1990年代のはじめにピークを迎えた後、減少が続いていた が、1990 年代の後半から一転して上昇に転じている。これら二つの指 標から、英国におけるホームレス問題は 1990 年代の後半から深刻化し ていることがわかる。

図 1. 住宅法に基づき受け入れられたホームレス世帯数

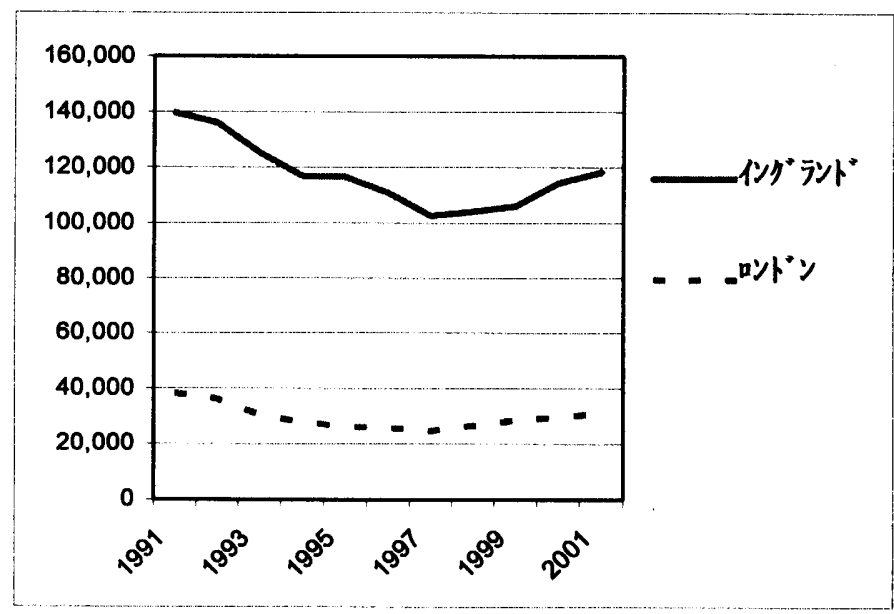

出典 : 英国副総理府 ${ }^{(8)}$

図 2．一時的宿泊施設に滞在するホームレス世帯数

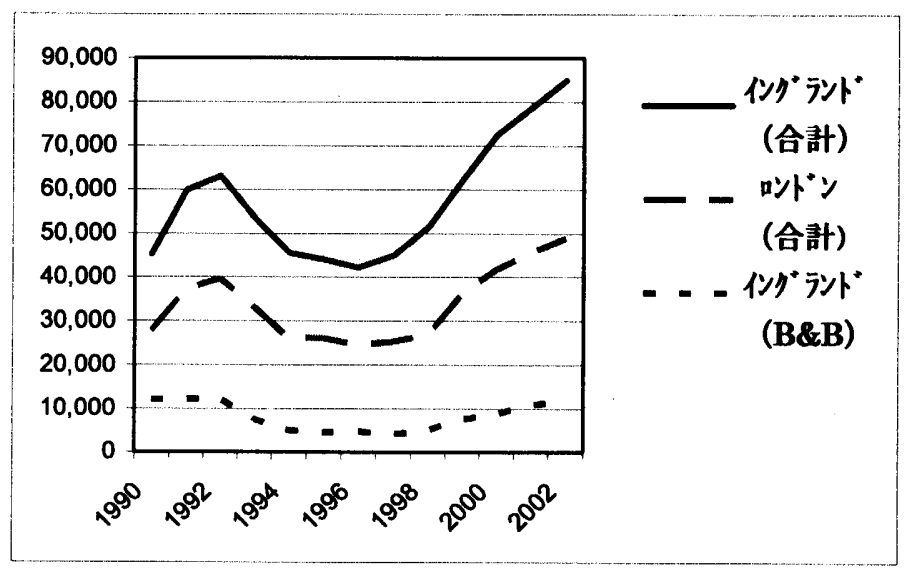

出典：英国副総理府 ${ }^{(8)}$

これに対して米国は、政府の责任で継続的にホームレス問題の深刻 度を示す指標のモニタリングを行う体制が整備されていないが 23)、ホ ームレス人口のおおまかなトレンドは、1970 年代後半から急增し、 1980 年代後半にピークを迎え 1990 年代は䉼減するものの 1970 年代よ りは谣かに高い水準にあるというのが一般的認識であるといわれてい る ${ }^{24)}$ 。本調查で筆者がインタビューした米国の関係者も、連邦ホーム レス対策庁の担当者も含め、全て同様の認識を示していた。また、近 
年の傾向についても、1990 年代の後半から米国におけるホームレス人 口が増加しているというのが一般的認識となっており、同じく本調查 で筆者がインタビューした米国の関保者全てが同じ認識を示していた。 連邦ホームレス対策庁の担当者は、その根拠として、裏付けとなる全 国レベルの実証的データは見当たらないものの、地方レベルではこう したトレンドを裏付けるデータが多くみられ、また、各地域の第一線 でホームレス対策に従事している関係者の大部分も同じ認識をもって いることを挙げていた。地方レベルでのデータの例としては、ニュー ヨーク市の一時的宿泊施設に滞在しているホームレス世帯の数が挙げ られる。図 3 に示すとおり、1999 年 11 月には月平均 5 千世帯強であ ったのが、2002 年 11 月には 9 千世帯弱にまで急増している。

以上のとおり、英米両国においては、1990 年代の終わりごろからホ 一ムレス人口が増加する傾向にあることがわかる。

図 3．一時的宿泊施設に滞在する世帯数（ニューヨーク市）

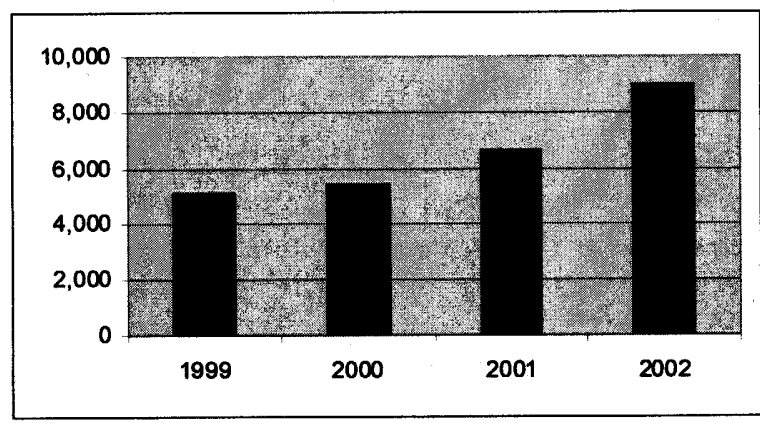

出典 : ニューヨーク市政府 ${ }^{(9)}$

4. ホームレス政策の動向 ${ }^{(10)}$

(1) 英国 ${ }^{(11)}$

英国のホームレス政策で非常に大きな比重を占めてきたのは、住宅 法に基づく地方自治体による一時的宿泊施設及び恒久的住居の提供で ある、所定の基淮を満たしホームレス世帯と認められるものは、地方 自治体に申請すれば、公営住宅を中心とした恒久的住居の提供を受け ることができるほか、恒久的住宅に入居するまでの期間、一時的宿泊 施設の提供が行われる。本手法が、英国のホームレス政策の中で重要 な役割を果たし続けているという点は不変であるが、近年、その政策 の枠組みに以下のような変化がみられる。

(1)野宿者対策

近年の英国におけるホームレス対策で特に重視されるようになって きているのが、道路、公園等屋外で寝泊りする野宿者への対策である。

野宿者の多くは、上述の住宅法による恒久的住宅の提供の対象とはな らない単身のホームレス ${ }^{(12)}$ である。こうしたグループのホームレスに 対して、英国政府は 1990 年より、野宿者に対する各種支援措置を導入 してきたが、1990 年代の後半までは、あまり大きな成果があがらなか った。この状況を打破するために、英国政府は、1998 年に約 1,850 人 と推計されていたイングランドの野宿者を 2002 年までに $2 / 3$ 以下にす ることを政策目標として宣言するとともに、1999 年に野宿者対策専門 の新たな部局（Rough Sleepers Unit）を設立し、野宿者対策の見直し を行った ${ }^{28)}$ 。

2001 年 11 月に英国政府が実施した調查によれば、イングランドに おける野宿者の数は 585 まで減少し、政府の宣言した政策目標が達成
された ${ }^{29)}$ 。

1999 年から 2001 年までの間に、政府の推進するプログラムに基づ き、 184 人分の緊急滞在施設、686 人分の一時的宿泊施設、757人分の 福祉サービスとセットとなった宿泊施設、4,207 人分の恒久的住宅が、 野宿者が集中するロンドンにおいて整備されている ${ }^{30) 。 し か し な か ゙ ら 、 ~}$ 筆者のインタビューした英国副総理府の担当者は、野宿者数の減少の 主たる要因は、こうした物的環境の整備ではなく、ソフト面でのサー ビスの充実にあるとの認識を示していた。本プログラムの事後評価に おいても、野宿者の減少に成功した最大の要因を、野宿者に直接コン タクトをとり個々のホームレスがどのようなサービスを必要としてい るかを分析する CAT (Contact and Assessment Team) と呼ばれるチーム の導入にあるとしている ${ }^{31}$ 。CAT は地域ごとに組織されるが、多くの 場合、競争的手続き経て政府と委託契約を交わした NP0 がコーディネ 一ター役をつとめる。CAT の最大の特徴は、あらゆる分野の専門家の 協力体制が整備されていることであり、一時的宿泊施設の提供サービ ス、福祉サービス、医療サービス、警察等の関係者のほか、薬物中毒、 精神障害等の専門家や若者向けのソーシャルワーカーなども加わり、 個々の野宿者の必要とする福祉的なサービスが的確に提供されるよう 最大限の配慮がなされている。また、CAT に係る委託先が競争的に決 定されたことに加えて、政府が野宿者の数に係る定量的な目標及びそ の達成期限を明確に設定したことが、野宿者対策に従事する関係者の モーティベーションを高め、実際にこれらの者が、現場での業務に费 やす時間が以前よりも増加したと報告されている ${ }^{32) 。 ~}$

(2) $\mathrm{B} \& \mathrm{~B}$ 対策

英国政府が、近年、ホームレス政策の中で特に力をいれているもう ひとつの点が、B\&B に滞在するホームレスの数の抑制である。図 2 に 示すとおり、ホームレ、ス世帯に提供される一時的宿泊施設のうち、B\&B が占める割合は小さくない。しかし、この B\&Bの活用は、様々な観点 から批判されている。B\&B の居住環境は、一時的宿泊施設として想定 されるものの中では最も低く、過密や非衛生的な環境は、特に子ども の健康及び教育に深刻な悪影響を与えると指摘されている ${ }^{33) ~ 34) 。 一 ~}$ 方で、コスト面についても、B\&B は一時的宿泊施設を提供するうえで 非常に割高の選択肢であるとされており、例えば、英国を代表するホ ームレス関連 NPO の SHELTER が行った推計によれば、民間穓貸住宅を 提供するのに比べて、B\&B はコストが約 3 倍になるとしている ${ }^{35)}$ 。以 上のとおり、最もコストパフォーマンスの悪い選択肢として問題点が 多いB\&Bであるが、図 2 に示すとおり、その活用は近年增加しており、 2002 年 3 月末で 11,820 のホームレス世帯が B\&B に滞在している。英 国政府は 1996 年 12 月に地方自治体に発した通達において、B\&B の活 用を最小限に抑えるよう指導してきたが、このような状況の中で、野 宿者対策と同様に、B\&B の利用抑制を専門とする新たな部局 (Bed and Breakfast Unit)を 2001 年に設立するとともに、2003 年 3 月には、2004 年 3 月までに、6 週間未満の期間で緊急的に入居する場合を除き、子 どものいる世帯が B\&B に入居することがないようにすることを政策目 標として宣言した ${ }^{36)}$ 。

英国政府は、この政策目標を実現するための具体的方策として、2002 年度予算で 3 千万ポンドの予算を確保し、B\&B を特に頻繁に使用して いる40の地方自治体に対して、この予算を活用して政策目標を実現す るための提案の提出を求めた。この結果、B\&B 以外の新たな一時的宿 泊施設の確保やホームレス世帯になりかかっている世帯への各種支援 
等地域の実情に応じた提案が行われ、提案された内容に基本的に基づ いた事業が展開されている。英国副総理府の本プログラムの担当者に よれば、これまでのところ本プログラムは効果的に展開されており、 参加した公共団体で、上述の B\&B の使用抑制に係る政策目標を既に達 成したものも多くみられるとのことであった。

(3) 2002 年ホームレス法

こうした近年の取組みの結果も踏まえて、英国政府は新たなホーム レス政策の枠組みを構築するため、2002 年に、2002 年ホームレス法 (Homeless Act 2002)を制定するとともに、新たなホームレス政策の戦

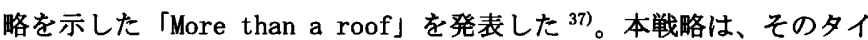
トルが示すとおり、住居の提供を極めて重視してきた従来のホームレ ス政策を見直し、関連する様々な福祉的サービス等を連携して提供す ることの必要性を強調している。つまり、英国のホームレス政策が、 福祉的サービス等の提供の推進も含めたより総合的なもの一転換しつ つあるとみることができる。この方針を具体化するうえで重視されて いるのが地方自治体の役割である。従来のホームレス政策でも、地方 自治体は、住宅法に基づき一時的宿泊施設及び恒久的住居の提供等大 きな役割を果たしてきたが、これらは中央政府によりデザインされた 制度的枠組みのもとで行われてきた。これに対して、2002 年ホームレ ス法では、地方自治体ごとにホームレス戦略に係る地方戦略 (Local strategy）を策定することを義務付け、政策のデザインの段階から地方 自治体がより染く関与することを求めている。英国副総理府の担当者 は、地方戦略の仕組みを導入した理由を 2 つ挙げていた。1つ目は、 地域の実情に即した政策デザインの必要性である。ホームレス政策の もとで提供されるサービスの内容が多様化しつつあるなかで、ホーム レス問題の特性が地域により差が存することを踏まえれば(13)、ホーム レスを救済するために必要となるサービスの内容も地域差があると考 えられる。このため、地域の実情を就知した地方自治体が中心となっ てホームレス政策の基本方針をデザインすることにより、より有効か つ効率的なホームレス政策の導入が可能になるという考え方である。 2002 年ホームレス法では、地方自治体の裁量により各地域のホームレ ス政策を弾力的に推進することができるよう、これまで住宅法に基づ く恒久的住居の提供の対象となっていなかった世帯についても、地方 自治体の裁量で恒久的住居の提供の対象に含めることを可能にしてい る。2 つ目の理由は、総合的なサービスな提供の前提となる関連部局 間の連擭及び関連する NPO との連携が、中央政府よりも地方自治体の ほうがより柔軟に実現できると考えられたためである(14)。

新たなホームレス政策に関する戦略で強調されているもうひとつの ポイントは、ホームレスの予防.(Prevention) の重要性である。 ここでいうホームレスの予防とは、ホームレスの状態になる可能性が 高い者が実際にホームレスとなることを䂆防するための措置をとるこ とをいう。英国副総理府の担当者によれば、この予防の重要性の強調 は、ある世帯がホームレスになってしまってから、ホームレスの状態 を脱するための支援を行うよりも、ホームレスとなるリスクが顕著に なった状態でホームレスになることを防ぐための手段を講じるほうが コストも低いとの考え方に基づいているとのことであった。具体的な 施策は、まだ開発途上の状況であるが、住宅法に基づく地方自治体に よる恒久的住居の提供の対象を、16-17 歳の者及び青少年用施設を出 たばかりの者で 18-20 歳のものに抎大したほか、上述の地方戦略の策 定にあたり、地域の実情に応じたホームレスの予防策を盛り込むよう、
英国副総理府が各地方自治体に働きかけている。

(2) 米国

米国においては、1980 年代から、連邦レベルでもホームレス政策が 導入されてきているが、その中心となっているのが、1987 年に制定さ れたマッキニー・ベント・ホームレス救済法 (McKinney-Vento Homeless Assistance Act) である。同法に基づき、連邦政府から、州政府、地方 自治体及びNPO に対してホームレス対策に係る様々な経済的支援が行 われている。同法に基づくプログラムの内容は、緊急的滞在施設、食 事、医療サービス、雇用支援、その他の福祉サービスなど多岐にわた っており、本法の導入は、米国におけるホームレス政策の発展に大き く貢献したとの肯定的評価も多い ${ }^{38)}$ 。しかし、その一方で、本法に基 づくホームレス政策の枠組みには批判も少なくない。例えば Wright らは、本法に基づくプログラムは、ホームレスのその日その日の生活 状況を改善するだけで、ホームレスとなる根本的な原因に影響を与え

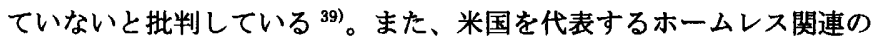
NP0 である National Coalition for the Homeless も、そもそも本法 は、ホームレス問題を解決する第一歩として緊急的に導入されたもの であり、より長期的な視野にたった政策の展開が、ホームレス問題の 解決に不可欠であると同様の批判をしている ${ }^{40)}$ 。同様の指摘は、米国 ホームレス対策庁が 1994 年に出版したレポートでも指摘されている。 同レポートは、本法に基づくプログラムは、ホームレスの生命や安全 を守るために緊急的に必要となる、いわゆるホームレス問題の症状面 にのみ対応するサービスを提供してきたが、ホームレスを根本的に解 決するための長期的な手段の展開には繁がっていないとしている ${ }^{41)}$ 。 (1)連綂的ケア (Continuum of Care Approach)の導入

こうした状況を背景に 1990 年代の後半から、連邦政府が導入を試み てきたのが連続的ケア (Continuum of Care Approach、以下「CoC」と 呼ぶ。）と呼ばれるアプローチである(15)。CoC は、ホームレスとなった 人々がホームレスの状態を脱出するまでの様々な段階、例えば、食事 や緊急的滞在施設などのいわゆる症状面一の対応が必要となる腎急段 階(Emergency stage)、通常の社会生活に戻るために個々人の能力の開 発を行う過渡的段階(Transitional stage)、そして定職と恒久的住居 を確保し通常の生活に戻る最終段階(Final stage)の全てにおいて必 要なサポートを行うことがホームレス問題の解決に不可欠であるとす る考え方である ${ }^{(16)}$ 。上述の米国におけるホームレス政策の発展の歴史 を踏まえれば、米国における $\operatorname{coC}$ の導入は、マッキニー・ベント法の プログラムが重点を置いてきた䋈急段階(Emergency stage)における ホームレス問題の症状面への対応だけでなく、過渡的段階 (Transitional stage)におおける各種トレーニングプログラムや最終段 階(Final stage)における恒久的住居の提供等も充実させ、より総合的 な施策体系を構筑することを意味する。この基本的な考え方のもと、 連邦政府のホームレス関倸のプログラムも見直しが始まっており、各 地域の関倸機関の連撘が実現し、CoC の考えが十分に反映された総合 的なサービス等の提供を行う事業に対してより多くの経済的支援を行 うことにより、 $\operatorname{CoC}$ の実現に向けた地域間の競争を促している ${ }^{42)}$ 。

この $\operatorname{CoC}$ の導入は、関係者の多くが肯定的に評価している。米国市 長会が行った調查によれば、主要都市の市政府の担当者の多くは、各 コミュニティーにおけるホームレス支援活動の有効性が、CoC の導入 により改善されたと認識している ${ }^{43)}$ 。さらに、Burt らにより 2002 年 に行われた $\operatorname{CoC}$ の事後評価も、 $\operatorname{CoC}$ の導入された地域の関係者の間で 
$\operatorname{CoC}$ の導入がより計画的なホームレス支援策の推進につながっている と肯定的に評価されていることを明らかにしている ${ }^{44)}$ 。同評価は、さ らに、 $\mathrm{CoC}$ の導入が、関倸者の間でのコミュニケーション及び情報の 共有を促し、より総合的な支援策の展開につながったと結論付けてい る。連邦ホームレス対策庁の担当者によれば、こうしたアプローチを さらに各地域で根付かせるため、連邦政府は、2002 年後半より、全米 各地の市の市長に対して、総合的なホームレス対策を展開するための 地域戦略の策定を進めるよう要請しているとのことであった ${ }^{(17)}$ 。

CoC の概念がホームレス政策に実際に反映されている代表的な具体 例としてあげられるのが、ニューヨーク市政府による一時的宿泊施設 の運営方法である ${ }^{(18)}$ 。

同市政府は、長年にわたり、ホームレスに対して大量の一時的宿泊 施設を提供していたが、ただ単に寝泊りする場所を提供するだけでは ホームレスが通常の生活に戻るのを促す効果が極めて小さいとの認識 のもと、ホームレスの状態を脱するのに必要となる能力を向上させる ための各種福祉サービス（例：カウンセリング、雇用支援、精神病・ 楽物中毒のケア等）を受けることを一時的宿泊施設に滞在する条件と する仕組みを導入している。このような宿泊施設は Programme bed と 呼ばれているが市政府が提供する宿泊施設の定員の約 8 割がこの仕組 みに基づくものとなっている。

また、 $\operatorname{CoC}$ の概念に関して注意すべき点は、本概念が各段階におけ るホームレスへの支援に加えてホームレスになる危険性の高い者がホ 一ムレスとなることを予防すること (Prevention) も含んでいること である。CoC の導入にあわせて、連邦政府の中でも、ホームレスの予 防を、最も費用対効果の高いホームレス抑制策として重視する傾向が あり、筆者がインタビューした連邦ホームレス対策庁長官のマンガノ 氏も、ホームレスの予防を今後米国のホームレス政策の最重点事項の ひとつに位置付けていく方針であり、刑務所や青少年用施設などを出 たばかりの者をサポートするプログラムを既に開始したほか、ホーム レス政策に係る地域戦略の策定にあたっては特にホームレスの予防を 重視するよう促していると語っていた。

(2)NPO との効率的な連携

連邦ホームレス対策庁の担当者によれば、上述の CoC を効果的に導 入し、ホームレス政策の費用対効果を向上させるための鍵となるのが、 ホームレスに対する様々なサービスの提供に関する経験を豊富に有す る NP0 の効果的かつ効率的な活用であるとのことであった。米国は、 英国をはじめとするヨーロッパ諸国に比べて、地方自治体における福 祉・住宅関連のサービスを供給する体制が整備されていないため、従 来よりもホームレス政策の執行に各地域の NP0 を活用してきた。NP0 の長所は、地方自治体を含めた政府組織のようにセクショナリズムが 少なく、様々なサービスを効率的にホームレスに対して提供するため の知見を有している点にあるといわれている。

こうした NPO の有する知見は、CoC の導入の流れの中でさらに重要 性が增すものと考えられているが、その一方で。NP0 による活動の効 率性について懸念を持つ関係者も多い。例えば、連邦ホームレス対策 庁長官のマンガノ氏は、非常に価値のある活動をしている NP0 が数多 くある一方で、非効率的な仕事をして存在価值のない NPO も少なくな いため、ただ単に NPO との連携を築くのではなく、効率的な NP0 とそ うでない NP0 との選別を的確に行い、NP との連携を効率的なかたち で進めることが、今後のホームレス政策を費用対効果を高めるうえで
重要であると語っていた。

連邦ホームレス対策庁の担当者が効率的にNPO の活用を進めている 先進例として挙げていたのがニューヨーク市の一時宿泊施設の運営で ある。ニューヨーク市政府がホームレスに対して提供する一時的宿泊 施設は、1980 年代までは基本的に市政府の直営であったが、1990 年代 に入ってからこれらの運営を、競争的な手続きを経て、順次 NPO への 委託に移行し、2002 年時点で 70 施設のうち 64 施設の運営を NP0 が行

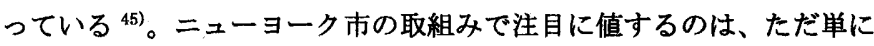
これらの施設の運営を外部に委託しただけでなく、委託を受けた NP0 がより効率的な運営を行うようなインセンティブを与える仕組みを整 備している点である。例えば、1998年より、こうした一時的宿泊施設 を出て恒久的住居に入居することが出来た者の数など施設のパフォー マンスを示す指標に応じて、最大で運営予算全体の $3 \%$ のボーナスが 運営主体の NPO に支払われる新しい委託契約の仕組みが導入されてい る。この仕組みの導入は、各施設の運営主体が住宅関連のサービスを 提供するスタッフを增員するという効果をもたらし、1998 年にこれら の施設から恒久的住居に入居した単身ホームレスの数は前年より 3 割 增加した ${ }^{46)}$ 。さらに、一時的宿泊施設の運営状況は厳しくモニタリン グされており ${ }^{(19)}$ 、第 3 者による抜き打ち検査の結果が将来の契約に反 映される。モニタリングにあわせて市政府は、モニタリングの対象と なる指標に係る目標水準を 1997 年より設定し、同水準の確保を促して いる。

この結果、設定された目標水準に達していない施設の割合は、1997

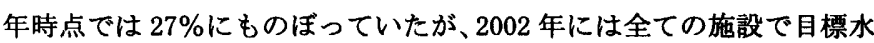
淮が達成された。ニューヨーク市の一時的宿泊施設は、以前は、多く のホームレスが利用することをためらうほど劣悪な環境で、他のホー ムレスからの暴行など安全面でも問題があるとされてきたが、こうし た一連の改革により、環境が大幅に改善されたと認識されている ${ }^{(20)}$ 。 (3)慢性的ホームレス(Chronically homeless) 対策

$\mathrm{CoC}$ による総合的な施策の展開と並んで近年の米国のホームレス対 策の大きな特徽となっているのが、長期的ホームレス対策の重点的実 施である。このアプローチの理論的根拠となっているのが Kuhn らによ るホームレスの分類に係る研究である。Kuhn らは、ホームレスを以下 の3つのグループに類型化している ${ }^{47)}$ 。

・過渡的ホームレス(Transitionally homeless)

一時的宿泊施設等に、一晚のみあるいは短い期間のみ滞在し、す ぐに恒久的住居などより安定的な居住形態に移っていくもの ・エピソード的ホームレス(Episodically homeless)

ホームレスの状態と通常の居住形稳との間を行ったりきたりする もの。一度ホームレスの状態になった後ホームレスの状態に留まる 期間に規則性はないが、合計しても数ヶ月以上となることは少ない。 ・慢性的ホームレス(Chronically homeless)

エピソード的ホームレスのようにホームレスと通常の状態の間を 行ったりきたりすることは少なく、一度ホームレスの状態になった 後ホームレスの状態に留まる期間が非常に長い。

この類型の考え方をベースに Kuhn らは、1980 年代末から 1990 年代半 ばまでのニューヨーク市の一時的宿泊施設の使用状況を上述の 3 類型 に分類した。この結果、慢性ホームレスの類型にあてはまると考えら 
れる者は、調查対象 73, 263 の約 1 割の 7.196 人になっており、過去に ホームレスとなった体験は平均 1.77 回で、ホームレス状態であった日 の合計が 133.6 日との結果となった。慢性的ホームレスは、他の類型 に比べて精神病や薬物障害の問題を抱えているものの割合が高く、ま た、特に注目に值するのが一時的宿泊施設へののべ宿泊人・日数が全

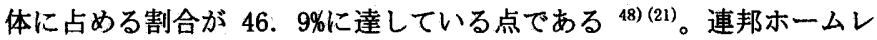
ス対策庁は、この研究結果に基づき、全体の 1 割にしか満たない慢性 的ホームレスが、ホームレス救済のための資源の半分を消費しており、 これらの者がホームレスの状態を脱することができるよう集中的にサ ポートを提供すれば、長期的にホームレス政策の費用対効果が上がる と主張している(22)。

これは、慢性的ホームレスがホームレスの状態を脱することができ れば、慢性的ホームレスのために使われてきた政策資源を、他の類型 のホームレスにまわせるという考え方に基づくものである ${ }^{(23)}$ 。

箨者がインタビューした連邦ホームレス対策庁長官のマンガノ氏も、 慢性ホームレス対策の重視は、ホームレス政策全体の効率性を上げる ためのものであるという点を綝り返し強調していた。

このような考え方のもと、2003 年度予算案において、現政権は、来 る 10 年間の間に慢性的ホームレスの解消を行うことを政策目標とし て揭げる旨宣言するとともに、慢性的ホームレス向けに福祉サービス がセットとなった恒久的住居の提供等を行うサマリタン・イニシアチ ブ (Samaritan Initiative) プログラムに 5 千万ドルの予算を確保す る提案を行った ${ }^{(24)}$ 。連邦ホームレス対策庁の担当者によれば、ホーム レス政策に関して、達成期限を明示した具体的な政策目標を揭げたの は、米国のホームレス政策の歷史の中でも初めての武みであるとのこ とであった。

5. 英米両国におけるホームレス政策の再構築の方向性

前章で概説したとおり、英米両国においては、1990 年代後半からホ ームレス問題の梁刻化の傾向を受けて、近年、そのホームレス政策の 内容が見直され、新しい方向性が打ち出されてきている。特に、財政 支出の抑制が先進国共通の政策課題となり、大幅な関連予算の増額が 期待されない中、ホームレス政策の効果を高めることが求められてい るため、いかにホームレス政策の費用対効果を向上させるかという点 がポイントとなっている。両国は、背景となる政治システム及び経済・ 社会的状況等並びにこれまでのホームレス政策の展開の方向性等の点 で大きな違いがあるが、近年のホームレス政策の再構筑の方向性につ いては、前章における分析により、以下のようないくつかの共通的な トレンドがあることが明らかになった。

(1)総合的アプローチ(Holistic approach)の採用

まず第一に挙げられるのは、両国とも、ホームレス政策の有効性を 向上させるため、従来と比べてより多様な政策手法を組み合わせる総 合的なアプローチ(Holistic approach)の採用を始めている ${ }^{(25)}$ 。

英国の場合は、住宅法に基づく恒久的住居の提供が長年にわたりホ ームレス政策の中で非常に大きな比重を占めてきたが(26)、新たなホー ムレス戦略である「More than a roof」及び 2002 年ホームレス法のも と、居住環境以外の分野のサービスの提供が強化されている。一方、 米国においては、 $\operatorname{CoC} の$ 概念のもと、緊急的段階 (Emergency stage)に おける支援策に過度の比重をかけるのではなく、過渡的段階 (Transitional stage)及び最終段階(Final stage)における施策も充実
させることに近年力点がおかれている(27)。

このように、その発展の方向性は違うものの、単一の政策手段のみ に過度に重点を置いたホームレス政策はホームレス問題の解決を図る うえで大きな効果を得られず、各種のサービスを地域の実情や個々の ホームレスの状況に応じて組み合わせて提供することが有効性の確保、 言い換えればより多くのホームレスがホームレスの状熊を脱せるよう にするために不可欠であるという認識が両国の関係者の間で共有され ているものと考えられる。

\section{(2)地方自治体の役割の強化}

総合的アプローチの導入は、ホームレス政策のガバナンスにも影䇾 を与えている。ホームレスに提供することが想定されるサーピスが多 様化したため、各地域ごと、あるいは、各ホームレスごとに、具体的 にどのようなサービスがホームレスの状熱を脱するのに必要となるか についてきめ細かな判断を行うことが必要となった結果、地方レベル でのホームレス政策の戦略の策定が両国で進められるなど、ホームレ ス政策のデザイン及び執行における地方自治体の役割が以前よりも大 きなものとなりつつある。

\section{(3)对象の重点化}

上述のとおり、ホームレス問題に対応するために投入される政策手 法についてはより広い螌囲のものが導入される傾向がある反面、その 対象については、特定のホームレスのグループにターグットを絞って 重点的に施策を講じる傾向が両国ともに見られる。米国では、ホーム レス政策の费用対勃果を長期的に改善する䧽点から、関連する政策资 源の大きな割合が消费されている慢性的ホームレスがホームレス政策 の主たるターグットとなりつつある。一方、英国においても、慢性的 ホームレスが大きな割合を占める野宿者への支援策が重点的に実施さ れている。英国の場合は、野宿者が、ホームレスの中でも最悪のかた ちで社会的に瑓外され、最もひどい環境にあることを重点的に対策を 講じる理由に挙げられることが多いが(28)、英国副総理府の担当者によ れば、米国と同様に、政策资源を定常的に消费しつづける傾向のある 野宿者の救済を重点的に実施することは、長期的にホームレス政策の 費用対効果を上げる効果があると期待されているとのことであった。 (4)ホームレスの予防(Prevention)の重視

ホームレス政策の経済効率性を改善するために、両国で重視されつ つあるアプローチのひとつがホームレスになる色険性が高い者がホー ムレスとなることを予防すること(Prevention)である。その理論的な 根拠となっているのが、これらの者がホームレスとなってからホーム レスの状態を脱することを支援するよりも、その前の段階でホームレ スとなることを予防するほうが、ホームレス人口を抑制するうえでよ り比較的費用対効果が優れているという点である ${ }^{(29) 。}$

両国とも、具体的政策手法の開発はまだ途上にあり、本アプローチ の効果を明確に実証する経験的データはまだ見当たらないものの、青 少年施設等を出たばかりの者をホームレスとならないようにするため のプログラムや地方レベルでの予防策の強化の促進等が両国で図られ ており、また、今後さらに本分野の施策が強化されることが予想され る。

(5)競争的環境のもとでの NP0 の活用

政府による各種のサービスの提供については、その効率性を向上さ せる観点から、できる限り民間主体の知見を活用するかたちで行い、 政府の直接的関与は少なくするというのが、先進諸国で共通の社会的 
要請になっているが、ホームレス政策の分野でも、NP0 を活用を通じ て関連政策の費用対効果を向上させることが大きな課題となっている。 ホームレス政策における NPO の活用は決して新しいテーマではなく、 米国においては、長年にわたりホームレス関連のプログラムの執行の 大きな割合が政府と委託契約を交わした NP0により担われてきた。ま た、英国の NPO は、米国に比べると関連政策への関与は小さかったも のの、地方自治体と連萼しながら一時的宿泊施設の提供等の役割を果 たしてきており、また、野宿者対策の分野では、さらに大きな役割を 果たしてきている。

しかしながら、近年のホームレス問題の深刻化を背景として、関連 政策の費用対効果を向上させることが強く求められているなか、ホー ムレス政策における NP0 の活用は、ただ単に NP0に委託するだけでは 不十分であるという認識が両国で広まっており、逆に、効率性の悪い NP0 を活用することは、ホームレス政策の執行に悪影響を与えかねな いという懸念も一部にみられる。この結果、近年の両国のホームレス 政策では、より効率性を高めるかたちでの NPO との連携が模索されて おり、例えば、明確かつ定量的な政策目標の提示、NPO の活動の事後 的評価の実施等委託先の NPO に競争的環境を用意する試みが両国で進 められている。

\section{6.まとめ}

本稿では、英米両国における近年のホームレス問題の状況を概説す るとともに、近年のホームレス問題の再深刻化を受けて、両国のホー ムレス政策がどのような方向に再構築されつつあるかを分析したが、 前章に示したとおり、両国における方向性が多くの共通点を有してい るとの結論を得た。これらは、いずれも限られた政策資源の中でホー ムレス政策の費用対効果をいかにして高めるかという議論からうまれ てきたものである。政策の対象範囲については、供給するサービスに ついてはより総合化をする反面、当該サービスの提供対象を一部の木 ームレスに重点化する方向性がみられ、また、ホームレスとなる危険 性が高い者がホームレスとなることを未然に予防することがホームレ ス政策の柱のひとつとなりつつある。また、ガバナンスの観点では、 地方自治体がより大きな役割を与えられる傾向にあり、また、NP0 の 活用をより効率的なかたちで進めることが大きな課題となっている。 ホームレス政策に係る長い歴史の中で、自らの政策執行の経験に基 づいて少しずつそのホームレス政策の枠組みを修正してきた英米両国 が、経済的・社会的等背景に差がありながら同じ方向にそのホームレ ス政策を再構築しつつあるという点は、ホームレス問題への対応の歷 史が比較的短い他の先進国等における今後のホームレス政策のデザイ ンに貴重な示唆を与えるものと考えられる。

前章で考察した方策が、ホームレス政策の費用対効果を改善するも のであるかについては、理論的な裏づけはある程度あるものの、経験 的事実による実証が十分に行われているわけではなく、経験的分析の 実施が今後の大きな課題と考えられる。こうした経験的分析の結果は、 前章に記したホームレス政策の再構築の方向性が、他の多くの国でも 適用可能な普遍性を有するものであるかという点も明らかにするもの と期待される。

\section{注积}

（1） ホームレス政策の概念は幅広く、その䉇囲に含みうる政策手段は多岐にわ
たるが、本稿では、これらのうち英米両国におけるホームレス政策の柱と なっている居住環境の改善に関する取り組みと各種福祉サービスの提供 に関する取り組みを中心に論じることとする。

（2）本稿は、英国におけるホームレス問題及びホームレス政策のうち、伷グラ゙ ドにおけるものについて論じる。

(3) これらの機関、著者による文献は多数存するが、本稿では主要なもののみ を参考文献にあげている。

(4) $\mathrm{OECD}$ で行われた調查の結果は、2003 年秋に開催された $\mathrm{OECD}$ 地域開発委貝 会の場で各区に政府代表者に報告されており、筆者は OECD の了承を得て 本論文を公表しています。

（5）本稿においては、論証に必要な文献が見当たらず、また、インタビューを 行った担当者にも亭づけとなる文献等の存在を確認したうえで、やむをえ ない場合に限り、インタビューの発言を論証に用いている。

（6） ホームレスの定義に係る議論は、筆者の別稿(文觔 22) を照されたい。な お、本稿ではホームレスの用語をそれぞれの国の中央政府の採用する定義 の意味で使用する。

（7）住宅法に基づき地方自治体が恒久的住居の供給を行うホームレス世带の データには、単身のホームレスの大部分が含まれておらす、、ホームレス人 口全体を示すものではない。

（8）英国副総理府が四半期ごとにホームページ等で公表しているデータによ る。

（9）筆者がニューヨーク市政府を訪問した際に、ホームレス政策部より提供さ れた資料による。

(10) 英米両国のホームレス政策の概要については、既に笔者の別稿 (文献 25〜 26)や他の文献（例えば文献 27）において紹介されているため、本稿にお いては詳細な解説は避け、近年の動向を中心に記述することとする。

（11）英国の中央政府におけるホームレス政策は、副総理府のホームレス局（当 時）に集約されつつあり、本節に記述された施策も同局の所管するもので ある。

（12）単身のホームレスであっても、高齢者・障害者等は、住宅法に基づく恒久 的住宅の提供等の対象となる。

（13）例えば、ロンドンにおけるホームレスは、他の都市に比べて、薬物依存や 精神障害のものの割合が一般に高い。

（14）筆者がインタビューした英国の関係者は、全てこの認識を共有していた。

（15）連邦政府内で CoC の導入に主導的な役割をしたのが住宅都市開発庁である。 同庁では、 $\operatorname{coc}$ の主要な 7 要素をアウトリーチ及びアセスメント (Outreach \& assessment)、緊急的滞在施設 (Emergency shelter)、一時的宿泊施設 (Temporary housing)、過渡的住宅 (Transitional housing)、恒久的サポ 一ト付き住宅 (Permanent supportive housing)、アフォーダブルな恒久 的住宅 (Permanent affordable housing)及び福祉サービス (Supportive service) としている。(文献 38)

（16）こうした、CoC 実現のためのプロセスを 3 つの段階に分類する考え方は、 例えば、文献 12 において提唱されている。

（17）例えば、2003 年 3 月に開催された会議において連邦住宅都市開発庁のマル チネス長官は、他の市に先駆けて地方戦略を策定したシカゴ市を賞数し、 他の市も同様の戦略を策定するよう促した。

(18) こューヨーク市政府の中でホームレス政策の統括を行っているホームレ ス政策部が本施策を所管している。

（19）例えば、施設の整備状況などの検査を行う。

(20) この点は、筆者がインタビューしたニューヨーク市政府の担当者だけでな く、ニューヨーク市のホームレス関連 NP0 の関倸者も同様の諰識を示して いた。

(21） 本調查において、Kuhn らは、ニューヨーク市だけでなく、フィラデルフィ ア市のデータについても分析し、同様の結果を得ている。

（22）例えば、2003 年 3 月の連邦ホームレス対策庁のマンガノ長官の演説及び 2002 年 7 月の連邦住宅都市開発庁マルチネス長官の演説はともにこの点を 強調している。

（23）この政策资源の効率的な活用の必要性も、Kuhn らの文献（文献 47）で強 調されているポイントである。

（24）サマリタンイニシアチブも含め慢性ホームレス対策は、主とし米国ホーム レス対策庁のイニシアチブで推進されている。

(25) “Holistic”と “Comprehensive”は日本語ではいずれも “総合的”と訳 されることが多いが、政策デザインの文脈では、後者が単に様々な政策手 段を組み合わせることを意味するのに対して、前者は、様々な政策手段を 相乗効果の谚出も意図しながら有機的に組み合わせることを意味する

（26）筆者が、1996 年にインタビムーした英国環境省（1996 年当時にホームレ ス政策を所管）の担当者は、英国政府内で、ホームレス政策の中で住宅供 給の占める比重が高すぎ、福祉サービスを担当する省庁等の势力が十分に 得られてなく、今後の大きな課題であると語っていた。

（27）ただし、過渡的段階及び最終段階でのサポートがまだまだ弱いとの批判は 根強く、筆者はインタビューした米国の NPO の担当者も同様の見解を示し ていた。

(28）例えば、文献 $28,29,31$ において、この点が強調されている。

(29）例えば、1986 年にドイツのコローニャ市で行われた調查によれば、ある世 帯がホームレスとなることを予防するための平均的コストは、当該世带が ホームレスになり一時的宿泊施設を提供する埸合の平均的コストの約 7 分 


\section{の1におさまる。(文献 49)}

\section{参考文献}

1) UK Office of Deputy Prime Minister: More than a Roof, UK Office of Deputy Prime Minister, 2002

2) UK Audit Commission: Housing the Homeless: The local authority role, HMSO, 1989

3) Shel ter : Bed and Breakfast - the way forward on-line document, 2002

4) Greve, J. and Currie, E.: Homeless in Britain, Joseph Rowntree Memorial Trust, 1990.

5) Balchin, P. :Housing Policy, Routledge, 1995.

6) Butler, K. Carlisle, B. and Lloyd, R. : Homelessness in the 1990s: Local authority practice, Shelter, 1994.

7) Niner, P. : Homelessness in Nine Local Authorities: Case studies of policy and practice, HMSO, 1989.

8) Randa11, G. and Brown, S. : Helping Rough Sleepers off the Street, UK Office of Deputy Prime Minister, 2002.

9) Burns, L., Smith, A.: The End id Bed and Breakfast?, Shelter, 1994

10) Hutson, S. and Liddaird, M. : Youth Homelessness: the construction of a social issue, Macmillan. 1994.

11) Fisher, $K$ and Collins, J.: "Access to health care", in Fisher, $K$ and Collins, J (eds) Homelessness health care and welfare provision, Routledge, 1993.

12) US Interagency Council on Homelessness: Priority : Home! The Federal Plan to Break the Cycle of Homelessness, US Interagency Council on Homelessness, 1994

13) US Department of Housing and Urban Development: A Report to the Secretary on the Homeless and Emergency Shelters, US Department of Housing and Urban Development, 1984.

14) National Coal ition for the Homeless: "NCH Fact Sheet 18: The McKinney Act" , on-line document, 1999

15) Basuuk, E. Rubin, L. and Lauriat, A. : "Is homelessness a mental heal th problem?" , American Journal of Psychiatry, 141: 12 December, 1984.

16) Belcher, J., Scholler, J. and Drummond, M. : " Three Stages of Homelessness: A Conceptual Model for Social Workers in Heal th Care" Health and Social Work 16, 1991.

17) Jencks, C. : The Homeless, Harvard University Press, 1995.

18) Tucker, W. : "How Housing Regulations Cause Homelessness" . Public Interest No. 102 Winter issue, National Affairs Inc, 1991.

19) 0' Flaherty, B. : Making room: the economics of homelessness, Harvard University Press, 1996.

20) Burt, M., Pollack, D., Sosland, A., Mikelson, K., Drapa, E., Greenwalt, K. Sharkey, P., Graham, A., Abravanel, M. and Smith, R. : Evaluation of Continuums of Care for Homeless People, Urban Institute, 2002.

21) Daly, G. : Homeless Routledge, London, 1996.

22）長谷川 典彦：OECD 諸国におけるホームレスの定義及びモニタリングに関 する門查 $-O E C D$ 諸国におけるホームレス政策に関する研究（その1）-、 日本建筑学会計画系論文報告集、第 588 号 pp. 141 146, 2005. 2

23）長谷川 典彦：再揭、2005. 2 .

24) Park, J. : "Increased homelessness and low rent housing vacancy rates" Journal of Housing Economics vol.9, 2000。

25）長谷川典彦: ニューホームレスー英米のホームレス問題とその对箖（その 1) 一、住宅、3月号、pp. 68〜 76, 1997.3

26）長谷川貴彦：ニューホームレスー英米のホームレス問題とその対策（その 2) 一、住宅、4 月号、pp. 95 105，1997.4

27）小玉徽、中村健五、都留民子、平川茂： 欧米のホームレス問題〈上〉実 管と政策、法律文化杜、2003

28) UK Department of Environment, Transport and Regions: Coming in from the Cold, UK Department of Environment, Transport and Regions, 1999.

29) UK Department of Transport, Local Government and the Regions : Coming in from the Cold: Progress Report on the Government's Strategy on Rough Sleeping, UK Department of Environment, Transport and Region, 2001.

30) UK Department of Transport, Local Government and the Regions : op. cit., 2001

31) Randa11, et al: op. cit., 2002.

32) Randa11, et al: op. cit., 2002.

33) UK Audit Commission: op. cit., 1989

34) UK office of Deputy Prime Minister: op. cit., 2002.

35) Shelter: op. cit., 2002.

36) UK Office of Deputy Prime Minister: Improving standards of accommodation for homeless households placed in temporary accommodations, UK Office of Deputy Prime Minister, 2003.

37) UK Office of Deputy Prime Minister: op. cit., 2002

38) Fuchs, E. and McAllister, W. : The Continuum of Care: A Report on the New Federal Policy to Address Homelessness, 1996
39) Wright, J., Rubin, B. and Devine, J. : Beside the Golden Door: Policy, Politics and the Homelessness, Aldine De Gruyter, 1998.

40) National Coalition for the Homeless: op. cit., 1999.

41) US Interagency Council on Homelessness: op. cit., 1994.

42) Burt, et al: op. cit., 2002.

43) US Conference of Mayors: A Status Report on Hunger and Homelessness in America's Cities, US Conference of Mayors, 2001.

44) Burt, et al: op. cit., 2002.

45) New York City Government: Reengineering Initiative, New York City Government, 2002.

46) New York City Government: op. cit., 2002.

47) Kuhn, R. and Culhane, D.: "Applying Cluster Analysis to Test Typology of Homeless by Pattern of Shelter Utilization: Results from the Analysis of Administrative Data" . American Journal of Community Psychology, Vol. 26, No. 2. 1998.

48) Kuhn, et al: op. cit., 2002.

49) Busch-Geertsema, v.: Insecurity of Tenure and Prevention of Homelessness in Germany, FEANTSA, 1995.

（2004年11月10日原稿受理，2005年 3 月 30 日採用決定） 